Vol. 9 (2): 245-250 (2019)

\title{
ANALYSIS OF EMISSIONS FROM DIESEL PASSENGER CARS IN NORTH MACEDONIA
}

\author{
Vlatko Dimitrov, Dame Dimitrovski* \\ Faculty of mechanical engineering in Skopje, North Macedonia; \\ "Corresponding author Dame Dimitrovski, e-mail: damedimitrovski@gmail.com;
}

Received February 2019; Accepted March 2019; Published April 2019;

DOI: https://doi.org/10.31407/ijees9203

UOI license: http://u-o-i.org/1.01/ijees/52136364

\begin{abstract}
The process of sharp increase in the presence of internal combustion diesel engines among passenger cars in the Macedonian fleet of vehicles, significantly increases its share in polluting emissions from the burning of diesel fuel in transport. Therefore proper analysis and accurate calculation of emission factors from diesel passenger cars and their pollution emissions will be calculated through the Tier 2 method for emission calculations from the European Environmental Agency. This study is based on data obtained from official institutions and their adequate approximation obtained results which give us an approximate figure to the actual situation of pollution from passenger cars with diesel Internal combustion engines.
\end{abstract}

Key words: Diesel vehicles, Emission factor, Tier 2, Air Pollution 